\title{
A riqueza escondida
}

\section{Livro discute a necessidade de as empresas mudarem sua menta-} lidade em relação ao mercado representado pelas populações de baixa renda. Para o autor, a identificação das necessidades do consumidor de baixa renda deve vir acompanhada de ação social e geração de valor econômico para empresas e populações.

por Juracy G. Parente e Edgard Barki FGV-EAESP

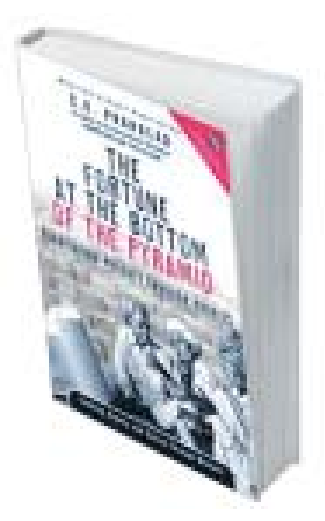

The fortune at the bottom of the pyramid C. K. Prahalad Wharton School Publishing, 2005

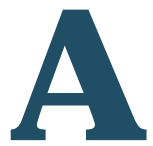

constatação de que o Brasil é um dos países com a maior concentração de renda do mundo não é nova. 0 fato é usado como argumento no discurso de homens públicos, desde políticos até ativistas comprometidos com causas sociais. $\mathrm{Na}$ mesma linha, são múltiplas as análises sobre as causas e as conseqüências dessa concentração, sendo a pobreza a mais evidente. Quanto a esta, os discursos e as ações também são variados e, por assim dizer, transdisciplinares, envolvendo o setor público e o privado e, mais recentemente, órgãos do terceiro setor. Tais ações distribuem-se em um amplo espectro, do assistencialista e paternalista até soluções mais maduras, baseadas no reconhecimento de um potencial intrínseco das camadas empobrecidas da população.

Pareceser este último caminho o que adota o professor Prahalad em sua mais recente obra, destinada a responder à pergunta que muitos, tanto hoje como no passado, fazem a si próprios: como combater a pobreza? No entanto, em vez de oferecer uma resposta populista à questão, ou então uma resposta puramente retórica, o autor propõe uma al- ternativa estabelecida a partir do equilíbrio entre princípios-chave, como, por exemplo, a busca de lucratividade, o bem-estar social eo crescimento conjunto de populações e empresas.

A solução encontrada pelo autor, e exposta em seu livro, é a de olhar para o dito mercado de baixa renda, hoje, paradoxalmente, o maior (em tamanho) mercado do mundo, e encontrar nele suas próprias necessidades em termos de produtos eserviços. Apesar de aparentemente simples, essa solução implica uma quebra de velhos modelos, sobretudo os da área de marketing de nossas empresas. Um desses modelos é, na verdade, um hábito estabelecido, que consiste no fato de as empresas desenvolverem seus produtos tendo, como parâmetro, os países de Primeiro Mundo, onde estão sediadas, e cuja distribuição de renda acaba resultando na predominância de uma opulenta classe média. Ora, o Primeiro Mundo e as classes opulentas do Terceiro Mundo respondem apenas por um terço da população mundial. Os dois terços restantes estão no Terceiro Mundo.

Isso significa que as empresas têm de desenvolver uma nova mentalidade no 
que diz respeito ao desenvolvimento e à gestão de seus produtos. As características próprias desse mercado demandam estratégias diferentes das usualmente empregadas pelas empresas nos países de Primeiro Mundo. Por exemplo, distância dos grandes centros urbanos; dificuldade no acesso ao crédito; problemas de formação básica, que impedem o próprio manejo dos produtos; restrições em infraestrutura, que podem prejudicar o desempenho do produto; e tamanho do mercado exigindo logística com operações de maior escala.

O utra característica do livro é o fato de ele não se restringir à teoria. Para exemplificar seus argumentos, Prahalad colecionou uma série de casos de empresas sediadas em países emergentes e que desenvolveram soluções adaptadas à cultura e às necessidades das populações de baixa renda. Além de inovarem e crescerem economicamente, essas empresas contribuíram ainda com a transformação da realidade social local e com a inclusão dessa população por meio do acesso ao consumo.

Um destaque à parte merece ser feito à experiência relatada da empresa brasileira Casas Bahia, reconhecida como tendo uma cultura voltada ao atendimento da extensa população de baixa renda do país. Um de seus maiores diferenciais é uma inovadora política de crédito, baseada no estímulo ao diálogo com o consumidor, no fomento de sua auto-estima e na expansão das aspirações de inclusão social de milhões de brasileiros.

Recomendamos a leitura deste livro em reconhecimento às idéias originais e inovadoras de seu autor em matéria de ações sociais da empresa que não prescindem da preocupação com inserção social. Em especial, Prahalad oferece pistas valiosas para que as empresas revejam seu próprio instrumental de relacionamento com seus mercados, tornandoo mais sensível para captar as necessidades, os val ores e a cultura dos consumidores desse vasto mercado representado pelas populações de baixa renda.

Juracy G. Parente

Prof. do Departamento de Marketing da FGVEAESP e coordenador do Gvcec - Centro de Excelência e Varejo

E-mail: jparente@fgvsp.br

Edgard Barki

M estrando em administração de empresas na FGV-EAESP

E-mail: barkis@uol.com.br 